\title{
Ampulla of Vater Cancer pNO TNM Finding V8
}

National Cancer Institute

\section{Source}

National Cancer Institute. Ampulla of Vater Cancer pNO TNM Finding v8. NCI Thesaurus. Code C134859.

Ampulla of Vater cancer with no metastasis to regional lymph nodes. (from AJCC 8th Ed.) 